\title{
Business Tax Burdens in Canada's Major Cities: The 2018 Report Card
}

\author{
by
}

Adam Found and Peter Tomlinson

- Before a business decides to locate or expand in a given jurisdiction, it must consider the tax implications of such an investment. Heavy tax burdens reduce potential returns, driving investment away to other jurisdictions and, with it, the associated economic benefits. Interjurisdictional comparisons of tax regimes are, therefore, important for businesses and the governments that seek to attract and retain them.

- Yet there are gaps in the way Canadian governments and analysts measure the overall tax burden on business investment, primarily because they exclude business property taxes. As in previous editions, we find this omission to be of major significance: business property taxes account for about half the total tax burden on business investment in municipalities we examine.

- Recognizing the US Tax Cuts and Jobs Act's importance, we have extended our examination to major American competitor municipalities, comparing them to the largest municipalities in our Canadian group. ${ }^{1}$ When only commonly analyzed federal and provincial/state business taxes are considered, the American and Canadian groups appear equally competitive. This is consistent with results obtained by other analysts. However, once property taxes and various local taxes are incorporated into the analysis the Canadian municipalities emerge with a notable competitive advantage. ${ }^{2}$

The authors thank Grant Bishop, Grant Humes, Enid Slack, Almos Tassonyi, members of the Fiscal and Tax Competitiveness Council of the C.D. Howe Institute and anonymous reviewers for comments on an earlier draft. The authors retain responsibility for any errors and the views expressed.

1 Having passed the United States Senate, the act is officially entitled "An Act to Provide for Reconciliation Pursuant to titles II and V of the Concurrent Resolution on the Budget for Fiscal Year 2018."

2 Our discussion of US cities is presented in the section entitled "Comparison of Canada with the United States" and in the online Appendix. Except where specifically noted, discussion elsewhere in the paper is limited to Canadian cities. 
Governments across Canada have made it a policy priority to reduce the marginal effective tax rate (METR) on new business investment. ${ }^{3}$ By incorporating various business taxes, the METR is a standardized and widelyaccepted composite measure of the burden business taxation places on new investment. ${ }^{4}$ As Canadian capital markets are small relative to the worldwide market, if the cost of investing in a particular Canadian jurisdiction is higher than the cost of investing elsewhere, that jurisdiction's capital stock will be smaller than it otherwise would be. The higher the METR, the greater the investment loss and overall economic harm arising from business taxation (Dahlby and Hassett (2016); Found (2017); Hassett and Hubbard (2002); Hassett and Newmark (2008)).

In this E-Brief, we build on earlier editions in this series by estimating the 2018 METR for the largest city in each province, focusing on corporate income taxes, retail sales taxes, land transfer taxes and business property taxes. As with similar analyses, our METR calculations exclude taxes not directly related to capital investment costs. ${ }^{5}$ Working with the general modelling framework developed in Found (2014), our METR findings reflect the tax burden on a hypothetical investment that has the same net-of-tax return regardless of where in Canada it is located. Given the extension of our analysis to the United States, we have updated our methodology to make our results comparable to those of Bazel, Mintz and Thompson (2018) who develop METR estimates for Canada, the United States and other countries.

Since METRs on capital investment began appearing in government budgets in 2006, the federal government and many provinces have reduced business taxes - such as those on corporate income, retail sales and corporate capital stock. However, sets of taxes commonly analyzed for METR estimation still exclude business property taxes, which are not only salient to investors but also considerably increase the rate of return an investment must yield to be economically viable. We find that business property taxes account for about half the total METR on corporate investment, a share much too large for METR analysts and Canadian governments to continue overlooking.

Having examined the largest municipality in each province, we find that Halifax, Charlottetown, Moncton, Montreal and Winnipeg have the highest overall tax burdens in 2018. ${ }^{6}$ On the more competitive side of the spectrum are St. John's, Toronto, Saskatoon, Calgary and Vancouver.

3 While many factors - such as agglomeration economies, climate, business taxes and public service benefits - affect inter-jurisdictional competitiveness for investment, the METR is designed and intended to measure business tax competitiveness only.

4 Given our methodological update as outlined in the online Appendix, the METR measures the percentage of the gross-of-tax return needed to pay business taxes on the marginal investment. For example, if the minimum acceptable rate of return on investment net-of-tax is 6 percent, and if investors need a gross-of-tax return of 10 percent to pay taxes and leave shareholders with a 6 percent return net-of-tax, the METR would be $(10-$ 6) $/ 10=40$ percent. Readers interested in model parameters and data in addition to information outlined in the online Appendix are invited to contact the authors through the Institute.

5 For example, value added taxes (e.g., Ontario's HST), payroll taxes, pension contributions, employment insurance premiums and municipal user fees do not directly affect capital investment costs. However, we include - to the extent possible - tax-based incentives such as investment tax credits and capital cost allowance deductions from corporate income; these features form part of the corporate taxation system, and thus they directly affect investment decisions.

6 The 2016 Census indicates Moncton has overtaken Saint John as the most populous municipality in New Brunswick. As of this edition, we have replaced Saint John with Moncton. 
Unfortunately, many governments have business property tax regimes that are complex and opaque, making them difficult for investors and other taxpayers to interpret and understand. As in recent editions in this series, we include a report card that evaluates business property tax regimes in terms of simplicity and transparency.

\section{Business Property Taxes}

An investment located within a province is also located within a municipality of that province. ${ }^{7}$ Investors must therefore consider locally generated business tax burdens as much as corresponding provincial and federal burdens when comparing alternative locations for investment. Given the predominance of business property taxes at the local level, METRs inclusive of these taxes paint a more accurate and complete picture of business tax competitiveness than do METRs exclusive of them. Moreover, METRs are also more comparable across jurisdictions when provincial business property taxes are included. ${ }^{8}$ Box 1 further details our rationale for including business property taxes in METRs, while Box 2 discusses the status of Ontario's particularly problematic business property tax.

Governments often structure their business property tax regimes such that effective tax rates differ from their statutory counterparts. ${ }^{9}$ Although each provincial and local property tax system is unique, we have developed a standardized methodology to transform statutory business property tax rates into estimated effective rates (Table 1). ${ }^{10}$ Depending on the availability and quality of relevant data, however, we need to support our methodology with certain assumptions on a case-by-case basis, as detailed in the online Appendix and/or in our previous editions.

We also continue to include business occupancy taxes in the METR as a component of business property taxation. The negative investment impact of a business occupancy tax is equivalent to that of a business property tax - whether the legal incidence falls on property owners or on tenants is irrelevant. By contrast, we continue to exclude business improvement area levies from the analysis, since spending financed by such levies is allocated not by governments, but by boards directly accountable to member businesses.

7 The exception is when the investment happens to be located in an area without municipal organization.

8 The level and mix of public services differ across provinces and, by extension, their municipalities. For example, highways, transit or social housing might be predominantly a municipal service in some provinces, but a provincial responsibility in others. Likewise, the distribution of services, revenue sources and intergovernmental grants between a province and its municipalities differs by province. Municipalities in a province with a generous provincial grant system, for instance, might rely less on property taxes than do municipalities in another province. METRs are more accurate, complete and comparable across jurisdictions when they include all relevant orders of government.

9 The difference between the statutory and the effective tax rate is illustrated by the following example. Suppose an investor owns real property that buyers would pay $\$ 100$ million to purchase. Due to lagged assessment, the property is assessed at $\$ 80$ million. The statutory tax rate - the rate applied to the property's assessed value - is 2 percent, resulting in a tax burden of $\$ 1.6$ million per year. However, the effective tax rate - the tax as a percentage of the market value - is only 1.6 percent ( $\$ 1.6$ million divided by $\$ 100$ million).

10 As is done to calculate group average METRs, group average tax rates are calculated by weighting individual rates by corresponding provincial corporate capital investment shares. Similarly, and as shown in the online Appendix, business property tax rates in Table 1 are assessment-weighted averages across business property classes (where applicable). 


\section{Box 1: Should METR Estimates Include or Exclude Business Property Taxes?}

Commenting on our initial draft, a reviewer drew attention to a statement in Bazel, Mintz and Thompson (2018):

"Municipal property taxes are excluded (from the three authors' METR estimates) since effective tax rates are not observable by industry or across countries. To measure municipal tax effects on investment exactly, the cost of municipal services that are directly funded by property levies should also be subtracted to arrive at the effective property tax rate."

Effective property tax rates are generally not observable due to assessment lags (see footnote 9). However some jurisdictions - Alberta for example - publish annual equalization factors which reliably convert statutory tax rates into effective rates. Other jurisdictions - New Brunswick for example - have assessment lags of a year or less, thus making statutory rates reliably close to effective rates.

These reliable effective rates have a substantial impact on METR estimates, which tells us that business property taxes should be included in the estimates. Even when assessment lags are longer than a year, and when equalization factors are unavailable - bringing methods described in our online Appendix into play - METRs with these taxes included will very likely be more accurate than METRs with them left out.

Referring to municipal property taxes specifically, Bazel et al. say the cost of municipal services should be deducted when estimating effective business property tax rates. A number of studies (e.g., Kitchen and Slack (1993), Hemson Consulting (2003), Mintz and Roberts (2006)) have aimed at quantifying this cost by estimating municipal expenditures assumed to benefit businesses.

Many municipal services - including costly ones such as policing and fire protection - are delivered jointly to businesses and residents. The cost shares of these classes are inherently unobservable, so judgement calls are inevitable in studies like those just cited. For example, Kitchen and Slack set the business share of policing and fire protection costs equal to the business share of total assessment. But no less plausibly, Hemson sets this cost share equal to a blend of assessment shares and the employment / population ratio.

Either approach is consistent with the key conclusion of these studies: i.e., the business share of benefits is lower than the business share of taxes. However the magnitude of this differential is critical to the effective tax-rate methodology proposed by Bazel et al. Their methodology would require choosing an effective tax rate from scores of possibilities when all municipal services and cost allocations are considered. This insoluble dilemma is avoidable by adopting the same methodology Bazel et al. adopt for the taxes they already analyze - i.e., limiting METR estimates to taxes alone, with the benefit of services funded by these taxes set aside.

Besides excluding municipal property taxes from METR estimates, Bazel et al. exclude provincial / state property taxes. Their statement does not comment on this exclusion, but their point regarding observability of effective tax rates applies to both levels of government. Our response is that estimating effective rates is feasible at both levels of government.

Since Bazel et al. compare METRs interprovincially and internationally, state and provincial property taxes are actually more relevant to their analysis than municipal property taxes. The large number of municipal taxing authorities in provinces and countries likely rules out including average municipal rates. This problem does not arise in the case of state and provincial property taxes. Excluding these taxes makes competitive rankings unnecessarily incomplete - and potentially misleading. 


\section{Box 2: Ontario's Indefensible Property Tax ${ }^{a}$}

Each year, Ontario's government sets discriminatory property tax rates: businesses in some municipalities pay higher rates than businesses in others, with no compensating difference in service levels. The rate spread is a legacy of school boards' taxing power, taken over by the province 20 years ago.

Since the takeover, the province has cut taxes at the high end of the rate range while avoiding tax increases at the low end. The impact has been reduced variation, but rates still vary widely. In dozens of municipalities - for example Kingston, London, Waterloo Region - businesses pay a ceiling rate (1.34 percent of assessed value). ${ }^{\mathbf{b}}$ At the other extreme, businesses in some isolated townships pay rates as low as 0.33 percent. However, more than 99 percent of the province's assessment base is taxed at rates between 0.89 percent (the commercial rate in Halton Region) and the 1.34 percent ceiling rate.

Tax cuts without tax increases entail revenue loss, but they also reduce the METR since the average rate goes down. After starting in 1998, the Progressive Conservative government's tax cuts had reduced revenue by $\$ 400$ million annually by the time it left office in 2003 .

The new Liberal government then suspended cuts until 2007. Its budget that year announced a $\$ 540$ million/ year tax-cut program to be rolled out from 2007 to 2014. In 2012, however, with cuts of about $\$ 240$ million/year implemented, the government again suspended tax cuts. The 2012 budget said the government was committed to resuming the tax-cut program in fiscal 2017/18, but the commitment was evidently not honoured: budgets in 2017 and 2018 said nothing about resuming the program.

The PC party, back in office this year, ran on a platform featuring $\$ 1.3$ billion/year in business tax cuts. All of the $\$ 1.3$ billion was needed for a one-point reduction to the corporate income tax rate; property tax cuts were not mentioned in the platform. However as McKenzie and Smart (2018) observe, most of the investment incentive achievable with a one-point corporate rate reduction can be achieved at substantially lower cost via accelerated depreciation allowances. Adopting their alternative would free up funding for property tax cuts. Ontario's 2018 fall economic statement said the province is prepared to implement accelerated depreciation allowances - provided the federal government does likewise. Soon afterward the federal government, in its own fall economic statement, said it indeed will do likewise.

As was estimated in Found and Tomlinson (2018), reducing the 2017 property tax rate ceiling to the Halton commercial rate would not just result in a uniform rate across 99 percent of the assessment base - effectively ending the discriminatory rate structure - but would reduce the province's METR by 1.6 points. The resulting reduction in provincial revenue would be about $\$ 0.97$ billion per year. ${ }^{c}$ By contrast, a $\$ 1.3$ billion CIT rate cut would reduce the METR by 0.7 points. Adopting the McKenzie-Smart alternative might permit attainment of both METR reductions, with revenue impact still in the $\$ 1.3$ billion vicinity.

a Discussion in this text box is based on Found and Tomlinson (2018), and on sources cited therein.

b The tax rate on properties with new buildings is 1.09 percent in municipalities where existing properties are taxed at higher rates. The residential property tax rate is uniform province-wide at 0.17 percent.

c Since we hadn't commenced using our updated methodology in Found and Tomlinson (2018), the METR reductions reported therein differ from those cited above. (See online Appendix for discussion of the update.) 


\section{Table 1: Effective Business Property Tax Rates - 2018}

\begin{tabular}{|l|ccc|}
\hline \multirow{2}{*}{\multicolumn{1}{c|}{ Municipality }} & Provincial & Municipal & Total \\
\cline { 2 - 4 } Vancouver & & Percent & \\
\hline Calgary & 0.423 & 0.639 & 1.062 \\
\hline Saskatoon & 0.406 & 1.469 & 1.875 \\
\hline Winnipeg & 0.498 & 0.686 & 1.184 \\
\hline Toronto & 0.586 & 1.879 & 2.465 \\
\hline Montreal & 0.823 & 0.966 & 1.789 \\
\hline Moncton & 0.000 & 3.558 & 3.558 \\
\hline Halifax & 2.205 & 2.475 & 4.680 \\
\hline Charlottetown & 0.339 & 3.035 & 3.374 \\
\hline St. John's & 1.500 & 2.360 & 3.860 \\
\hline Group Average & 0.000 & 1.971 & 1.971 \\
\hline Source: Authors' assessments. & $\mathbf{0 . 4 9 3}$ & $\mathbf{1 . 5 4 7}$ & $\mathbf{2 . 0 4 0}$ \\
\hline
\end{tabular}

\section{Business Property Tax Report Card:The Ease of Estimating Effective Tax Rates}

We use our Business Property Tax Report Card to assess the ease with which investors can determine effective business property tax rates in a given jurisdiction (Table 2). This determination can be easy - or almost impossible - depending on (i) structural features of a jurisdiction's assessment and tax policies and (ii) information that jurisdictions make available.

We rate structural features based on their simplicity. Ideally, property assessments would be based on a market valuation date no more than a year before the year of taxation, while a uniform statutory tax rate would apply to all business property. In this ideal state, the jurisdiction would levy a uniform effective tax rate, and show the rate on tax bills. Typically, however, provincial governments introduce complexities such as multiple business classes with differential tax rates, discounts applying to specific assessment categories and valuation dates several years behind the year of taxation. These complexities undermine simplicity.

As for the information governments make available, we rate it based on transparency. If relevant information is difficult to find on websites or if it is presented in obscure terms, investors will have difficulty estimating effective tax rates - even in jurisdictions with relatively simple assessment and tax policies. By contrast, public availability of relevant information can mitigate the difficulties of accounting for complex structural features. Unfortunately, however, provincial governments - along with the assessment agencies and municipalities they control - often place a cloak of secrecy over information needed to estimate effective property tax rates, needlessly undermining transparency. 


\begin{tabular}{|c|c|c|c|c|c|}
\hline \multirow{2}{*}{ Province } & \multicolumn{2}{|c|}{ Provincial BPT Regime } & \multicolumn{2}{|c|}{ Municipal BPT Regime } & \multirow{2}{*}{$\begin{array}{c}\text { Overall } \\
\text { Grade }\end{array}$} \\
\hline & Simplicity & Transparency & Simplicity & Transparency & \\
\hline British Columbia & B & A & B & A & $\mathrm{A}$ \\
\hline Alberta & B & $\mathrm{D}$ & $\mathrm{C}$ & B & $\mathrm{C}$ \\
\hline Saskatchewan & $\mathrm{C}$ & $\mathrm{D}$ & $\mathrm{C}$ & B & $\mathrm{C}$ \\
\hline Manitoba & $\mathrm{C}$ & $\mathrm{D}$ & $\mathrm{F}$ & $\mathrm{C}$ & $\mathrm{D}$ \\
\hline Ontario & $\mathrm{F}$ & F & $\mathrm{C}$ & B & $\mathrm{D}$ \\
\hline Quebec & $\mathrm{D}$ & $\mathrm{D}$ & $\mathrm{D}$ & B & $\mathrm{D}$ \\
\hline New Brunswick & B & A & A & A & A \\
\hline Nova Scotia & B & $\mathrm{D}$ & $\mathrm{D}$ & B & $\mathrm{C}$ \\
\hline $\begin{array}{l}\text { Prince Edward } \\
\text { Island }\end{array}$ & A & A & A & B & A \\
\hline $\begin{array}{l}\text { Newfoundland } \\
\text { and Labrador }\end{array}$ & - & - & B & B & B \\
\hline National Average & C & $\mathrm{D}$ & $\mathrm{C}$ & B & $\mathrm{C}$ \\
\hline
\end{tabular}

As stated in our previous editions, our report card gives an overall grade for provincial performance, even though it has separate provincial and municipal grading sections. Both of these components are controllable by provincial governments. It would be difficult to rank municipalities across provinces fairly, given the different constraints imposed by their provincial governments.

Using the methodology we developed in 2015 , we again evaluate simplicity and transparency separately by assigning numerical scores based on a qualitative assessment of the provincial-municipal business property tax regime and then translating these scores into letter grades (see Table 2). With no appreciable change in the business property tax regimes, scores remain as they were in 2017. ${ }^{11}$ The overall assessment of a province is the simple average across its four scores, whereas national scores are weighted averages with provincial capital investment shares applied as weights, as done in Table $1 .^{12}$

We evaluate each jurisdiction against the following ideal: the effective business property tax rate applicable to a property investment is readily ascertainable from a government website. None of our 20 jurisdictions (10 provinces and the largest city in each province) currently meets this ideal; Canadian governments have much to

11 Moncton has inherited Saint John's scores given the absence of any appreciable difference between the two municipalities in terms of business property tax regime simplicity and transparency.

12 Since Newfoundland and Labrador has no provincial business property tax, it is excluded from the provincial component of the report card and, by extension, from the calculation of average scores. 


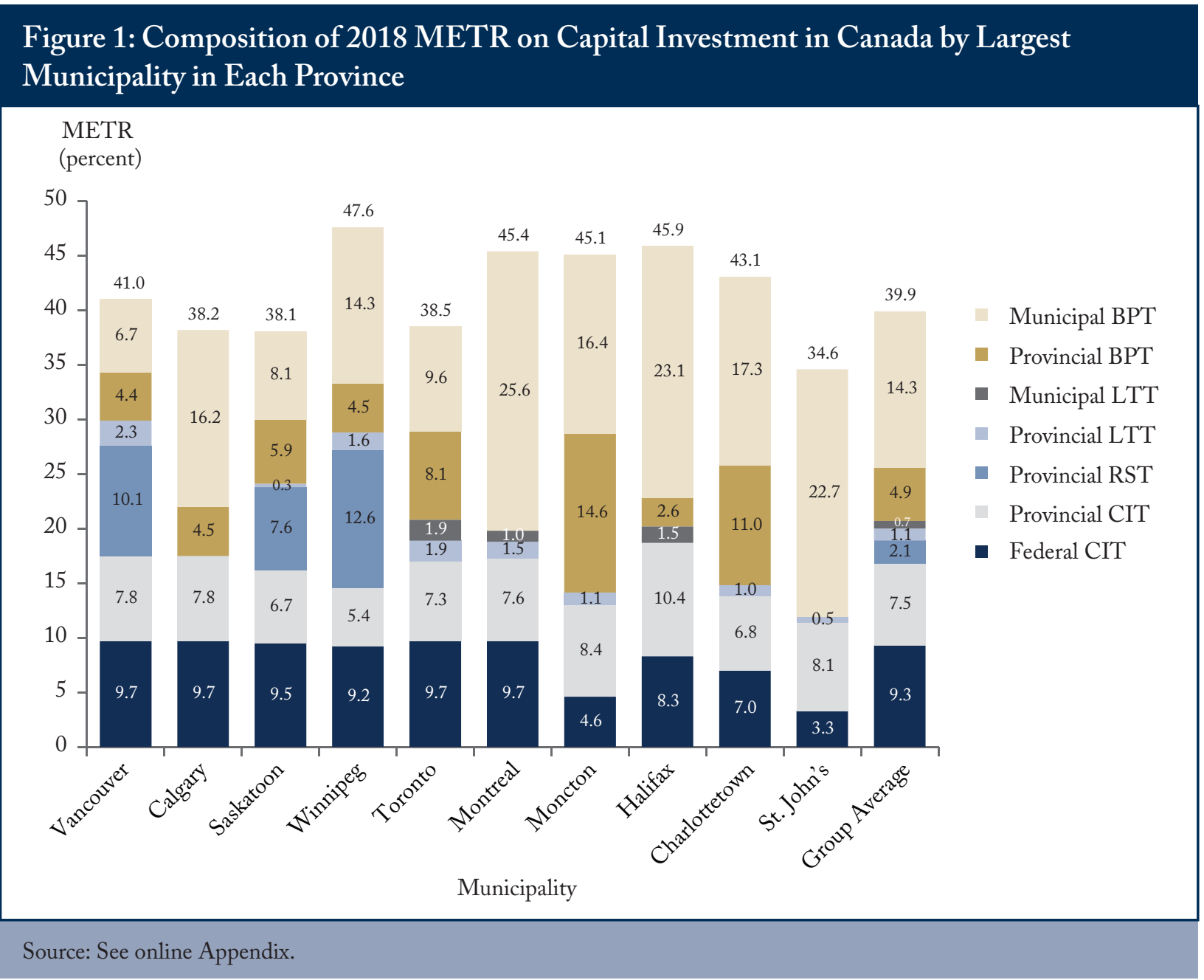

improve upon in making their business property tax systems simpler and more transparent. When simplicity and transparency are jointly considered, the top-scoring provinces are New Brunswick, Prince Edward Island and British Columbia, whereas Manitoba, Ontario and Quebec are the lowest performers (see Table 2).

\section{The Effect of Business Property Taxes on the METR}

Most Canadian METR estimates, such as those developed by School of Public Policy at the University of Calgary, generally indicate that the four Atlantic provinces have the lowest METRs. Upon incorporation of business property taxes, however, our results point to substantially different rankings. With the exception of St. John's, we find that the tax burdens in the largest cities in the Atlantic provinces are higher than in all other cities but Winnipeg. St. John's enjoys the most competitive position, followed not too distantly by Calgary, Saskatoon and Toronto, with Vancouver near the group average (Figure 1). ${ }^{\mathbf{1 3}}$

13 The variables represented by acronyms in Figures 1-3 are as follows: corporate income tax (CIT); retail sales tax (RST); land transfer tax (LTT); business property tax (BPT). 
The largest provincial tax burdens are in British Columbia, Manitoba and New Brunswick. In all these provinces, provincial business property taxes are substantial barriers to new business investment. In British Columbia, Saskatchewan and Manitoba, retail sales taxes still represent a sizable burden, while provincial corporate income taxes remain substantial barriers to new business investment in all provinces.

As for municipal business tax burdens, these are highest in Montreal, Halifax and St. John's while near the group average in Calgary, Winnipeg, Moncton and Charlottetown. Vancouver showcases the most competitive municipal business tax environment, followed by Saskatoon and Toronto.

\section{Comparison of Canada with the United States}

As noted by Bazel, Mintz and Thompson (2018), the United States' business tax cuts have substantially enhanced that country's business tax environment. The centrepiece of this reform is a marked reduction in the federal corporate income tax rate, from 35 to 21 percent, effective January 1, 2018. Naturally, such a shift in the business tax landscape would lead METR analysts and Canadian governments to wonder: Are Canada's largest cities now outcompeted by their counterparts in the United States? To help answer this question, we have extended our analysis to five American cities: Boston, New York, Chicago, San Francisco and Los Angeles. The online Appendix includes a section outlining the methodology and data we employed for this purpose.

In this section we compare the five American cities (the "US-5"), with the five largest cities in our Canadian group (the "CA-5"). When only commonly analyzed business taxes (i.e., corporate income taxes and provincial/ state non-value-added sales taxes) are considered, the United States' tax reform appears to leave that country and Canada equally competitive: the US-5 average METR for these taxes is 19.2 percent whereas it is 19.1 percent on average for the CA-5 (see Figure 2). However, once provincial/state property taxes and land transfer taxes are incorporated, along with local taxes, these METRs become 49.5 and 40.2 percent respectively - a notable advantage for Canada (see Figure 3). ${ }^{14}$

While the Tax Cuts and Jobs Act has made the United States considerably more competitive, our results suggest there is still a Canadian advantage. This advantage is in fact understated in Figure 3 since data limitations prevented inclusion of certain local business taxes (e.g., gross receipts taxes) levied in some US-5 cities.

When investors evaluate locations, they have to look at alternative cities as well as alternative countries, provinces and states. While average METR results for 10 cities won't necessarily apply to all of urban North America, they could prompt investors looking only at US locations to look northward.

\section{Recommendations and Conclusions}

Governments and METR analysts need to begin including business property taxes in METR estimates, given such taxes account for about half of the total METR. Otherwise, prevailing METR estimates will continue to paint inaccurate pictures of overall business tax competitiveness and related policymaking. A case in point is our US-5 vs. CA-5 analysis in which Canada's competitive advantage over the United States - at least in these 10 cities - is overlooked when only commonly analyzed business taxes are considered.

14 Two of the US cities (San Francisco and Los Angeles) have gross receipts taxes with rates varying widely across industries. While these taxes negatively affect investment, data limitations preclude their inclusion in our METR model at this time. 


\section{Figure 2: Composition of 2018 METR on Capital Investment with Federal and State/ Provincial CIT and RST Only: US-5 vs. CA-5}

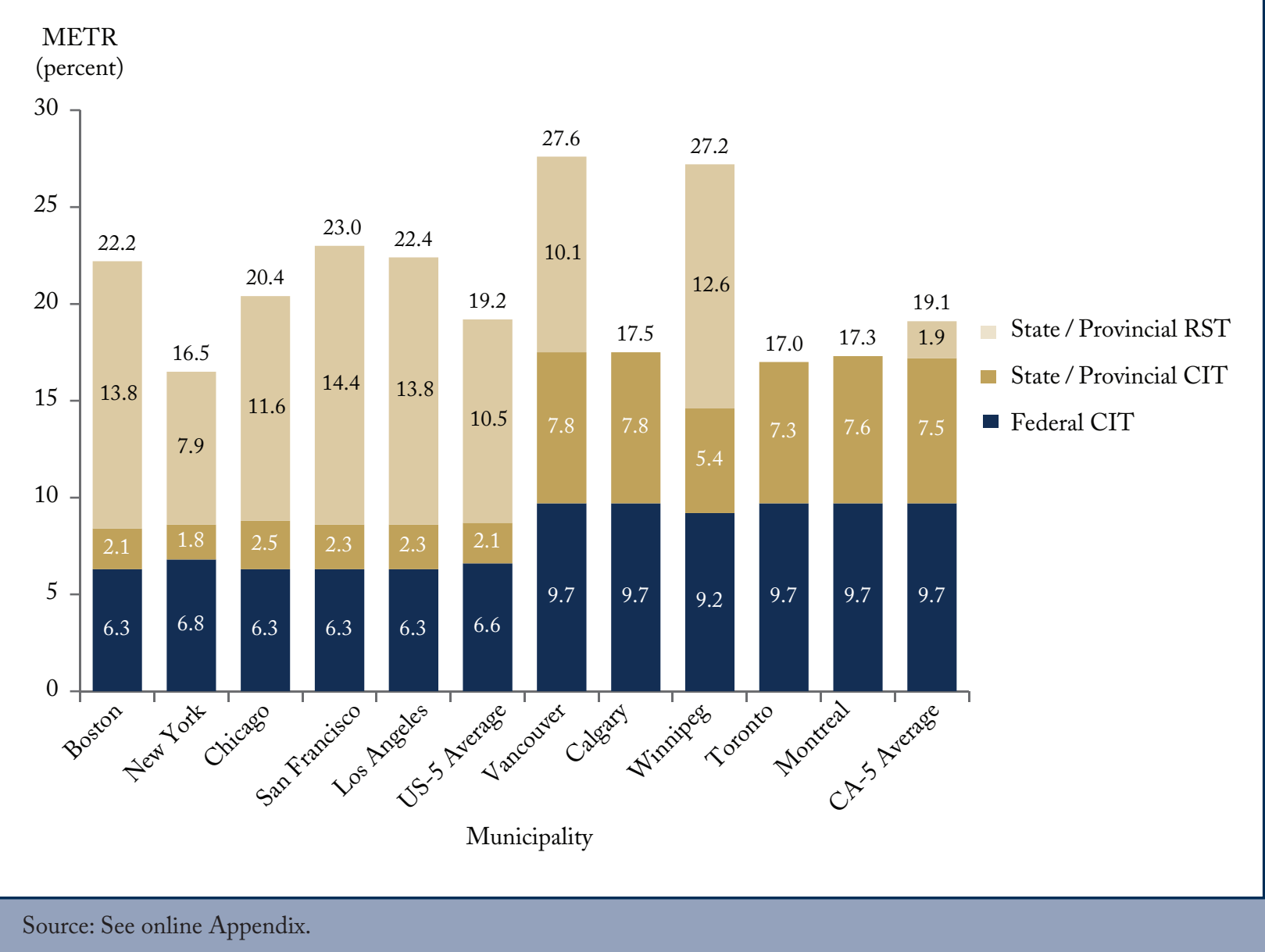

Once governments better understand the effect of business property taxes on competitiveness, they are more likely to reduce the burden these taxes impose. To facilitate the inclusion of business property taxes in METR estimates, provincial governments should simplify their property tax systems and make the data needed to determine effective property tax rates readily and freely available. ${ }^{15}$

Also, as we have argued previously, provinces should not call their provincial property taxes "education taxes," since that label is misleading. All provincial property taxes function as general revenue taxes, but only New Brunswick and Prince Edward Island label them appropriately. Provincial governments elsewhere might hope the misleading education label will mitigate taxpayer discontent. However that objective, insofar as it is achieved, undermines accountability.

15 Some state agencies in the US (for example in New York and Illinois) publish annual equalization factors for local jurisdictions; these factors enable investors to easily translate statutory property tax rates into effective rates. 


\section{Figure 3: Composition of 2018 METR on Capital Investment with All Business Taxes at All Levels of Government: US- 5 vs. CA-5}

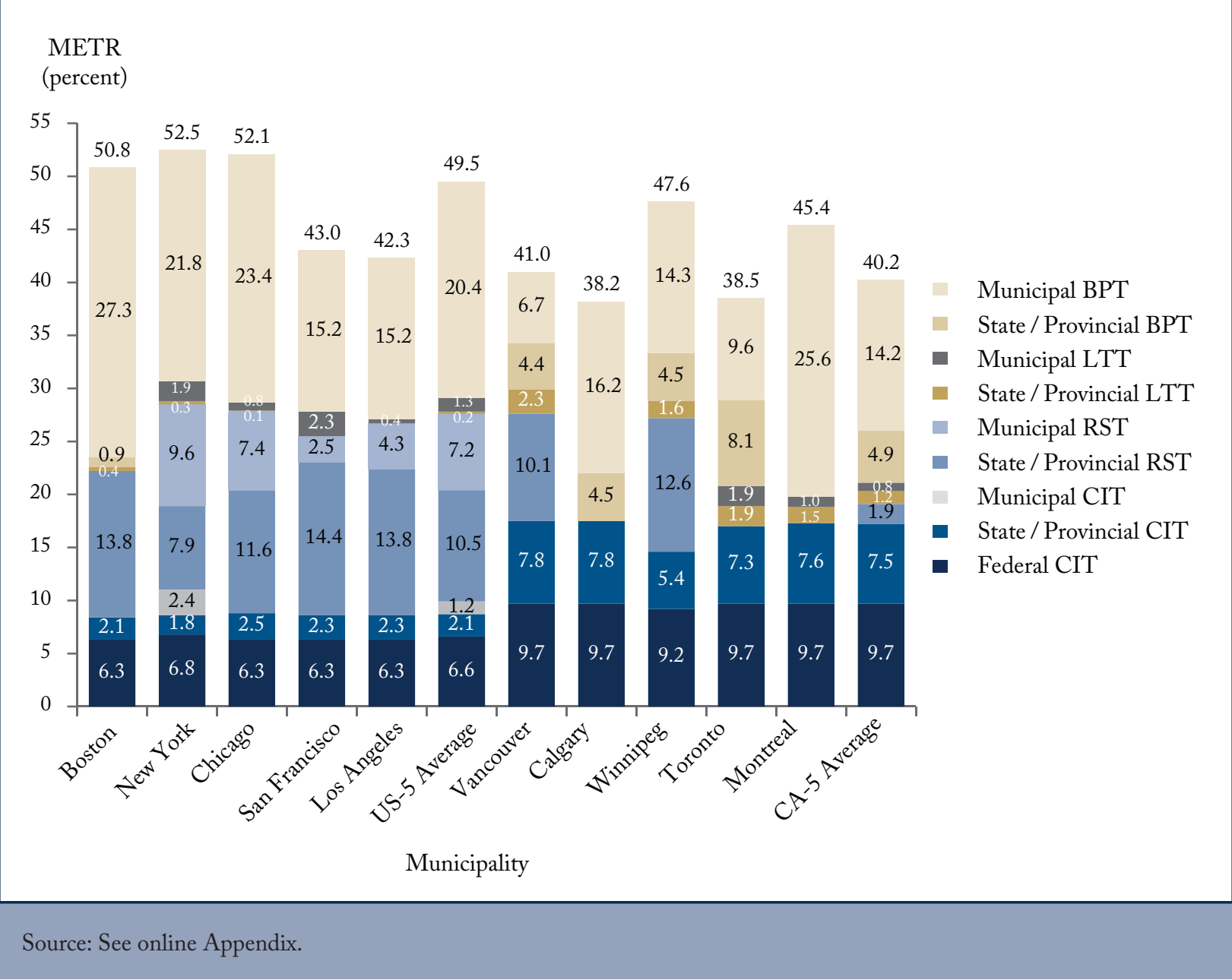

Despite years of concerted provincial and federal efforts to reduce the tax-related cost of business investment, METR analysts and Canadian governments need to address a gap in their METR monitoring. A major tax on business investment - the business property tax - has been missing from prevailing METR estimates. Correction of this omission by analysts and governments would provide more accurate estimates of the tax burden governments impose on investment. 


\section{References}

Bazel, Philip, Jack Mintz, and Austin Thompson. 2018. “The 2017 Tax Competitiveness Report: the Calm Before the Storm. Calgary: School of Public Policy Publications 11:7.

Dahlby, Bev, and Kevin Hassert. 2016. "The Economic Effects of the Corporate Tax: A Review of the Recent Literature." Paper presented at the School of Public Policy Conference on the Corporate Income Tax (University of Calgary).

Found, Adam. 2014. "Business Property Taxes and the Marginal Effective Tax Rate on Capital." In "Essays in Municipal Finance." PhD diss. University of Toronto.

.2017. "Flying Below the Radar: The Harmful Impact of Ontario's Business Property Tax." E-Brief 266. Toronto: C.D. Howe Institute. November.

Found, Adam, and Peter Tomlinson. 2018. "Business Tax Cuts in Ontario: Expanding the Menu." Intelligence Memo. Toronto: C.D. Howe Institute. July 5.

Hassett, Kevin A, and R. Glen Hubbard. 2002. “Tax Policy and Business Investment” In Alan Auerbach and Martin Feldstein eds. Handbook of Public Economics 3. Elsevier.

Hassett, Kevin A., and Kathryn Newmark. 2008. "Taxation and Business Behaviour: A Review of the Recent Literature" in John W. Diamond. and George R. Zodrow eds. Fundamental Tax Reform: Issues, Choices and Implications. Cambridge MA: MIT Press.

Hemson Consulting Ltd. 2003. “Toronto Office Buildings: Analysis of Municipal Revenue and Costs.” Report prepared for the Canadian Institute of Public and Private Real Estate Companies (now the Real Property Association of Canada), Toronto, ON.

Kitchen, Harry, and Enid Slack. 1993. "Business Property Taxation.” Discussion Paper prepared for the Government and Competitiveness Project, School of Policy Studies, Queen's University, Kingston ON.

McKenzie, Kenneth, Mario Mansour, and Ariane Brule. 1998. "The Calculation of Marginal Effective Tax Rates.”Working Paper 97-15. Ottawa: Technical Committee on Business Taxation, Department of Finance.

McKenzie, Kenneth. 2016. "Inside the Black Box: Marginal Effective Tax Rates in Canada - A Primer." Canadian Tax Journal. 64 (4).

McKenzie, Kenneth, and Michael Smart. 2018. "How to Fight Trump's Stealth Attack on Canadian Business."Toronto: The Globe and Mail. August 24.

Mintz, Jack M. and Tom Roberts. 2006. Running on Empty: a Proposal to Improve City Finances. Commentary 226. Toronto: C.D. Howe Institute.

This E-Brief is a publication of the C.D. Howe Institute.

Adam Found is Metropolitan Policy Fellow at the C.D. Howe Institute and Course Instructor,

Department of Economics, Trent University.

Peter Tomlinson is a Sessional Lecturer, Department of Economics, University of Toronto.

This E-Brief is available at www.cdhowe.org.

Permission is granted to reprint this text if the content is not altered and proper attribution is provided.

The views expressed here are those of the authors. The C.D. Howe Institute does not take corporate positions on policy matters. 